\title{
Corporate governance and the environment: Evidence from green innovations
}

\author{
Mario Daniele Amore \\ Bocconi University
}

Morten Bennedsen

INSEAD

April 8, 2013

\begin{abstract}
We present causal evidence of corporate governance effects on firms' environmental performance. Using changes in takeover legislation as exogenous variations in corporate governance quality, we show that worse-governed firms generate fewer green patents relative to all their innovations. This effect is greater for firms with a smaller share of institutional ownership, with a smaller stock of green patents, and operating in states with lower pollution abatement costs and in industries less dependent on energy inputs. Our results are consistent with "quiet life" interpretations whereby worse-governed managers avoid complex projects that would entail major changes in the firm's status quo.
\end{abstract}

Keywords: corporate governance, environment, green patents

JEL classification: G34, O31, Q20

\footnotetext{
We thank Raffaella Sadun as well as participants at the CEPR/IGIER Workshop on Incentives, Management and Organization and at the INSEAD brownbag seminar for useful comments and suggestions. All errors remain our own.
} 


\section{Introduction}

Global climate change is the greatest economic and social challenge that humanity faces in the foreseeable future. Although researchers have addressed some important determinants of environmental efficiency —including public policies (Jaffe et al. 2002; Johnston et al. 2010), energy prices and technology (Popp 2002; Martin 2010), and other firm-specific factors (De Canio and Watkins 1998; Cole et al. 2007) — there is still much variation across firms that remains unexplained. Scholars have thus begun paying increased attention to the effect of leadership on environmental policies. For instance, the effects of managerial and governance quality on energy efficiency (Bloom et al. 2010) and on pollution outcomes (Kock et al. 2011) have been studied. The prevailing view of extant research is that good governance is positively correlated with firms' environmental efficiency. Yet as some have acknowledged (e.g. Bloom et al. 2010), the literature has been unable to identify the direction of causality in the nexus between corporate governance and environmental outcomes.

This paper provides causal evidence that worse corporate governance reduces firms' environmental innovation when the latter is measured as the number of "green" patents - that is, patents related to environmental technologies. Existing works have documented that green patents represent a key driver in reducing toxic emissions (Carrion-Flores and Innes 2010). Our contribution is thus twofold. First, by investigating the effect of corporate governance on green patents, we document a specific channel through which good governance effectively reduces pollution. Second, we use changes in takeover legislation to establish the direction of causality between the observed environmental policies of firms and their quality of corporate governance.

Linking US Compustat firms with the NBER patent data set, we exploit information on the technological class of patents to identify environment-related (green) innovations. We then adopt a difference-in-differences approach based on the passage of business combination (BC) laws in US states during the second half of the 1980s. These laws had a negative effect on the quality of corporate governance because firms incorporated in the legislating states became more able to defend against uninvited takeovers, which in turn increased managerial slack (Bertrand and Mullainathan 2003). The staggered passage of BC laws across states provides geographic and time variations in the quality of corporate governance. Moreover, 
given that $\mathrm{BC}$ laws affected firms in their state of incorporation, we can exploit the discrepancy between state of headquarters and state of incorporation to control for geographic effects.

Our main result is that, following the passage of BC laws, firms experienced on average a $7 \%$ reduction of green patents in their portfolio. This result is robust to various checks, such as the exclusion of Delaware (where many US firms are incorporated), firms headquartered in California (where innovation is concentrated), and firms incorporated in states that never passed a BC law.

We also derive four results that show how the negative impact of $\mathrm{BC}$ laws on green patenting varies with the opportunity costs of reducing environmental innovation. First, a larger stock of green innovations reduces the reduction in green patents induced by the $\mathrm{BC}$ laws. Second, the effect is more pronounced in sectors characterized by less energy dependence. Third, the effect is larger for firms operating in states with a lower cost of pollution abatement. Fourth, the negative effect of BC laws on green patents is mitigated by the stake of institutional ownership within the firm. Taken together, our results suggest that economic and governance incentives interact to determine firms' green activities: The effect of introducing BC laws is less when firms have strong internal governance incentives (as measured by size of institutional ownership) and/or strong economic incentives to engage in green innovation (as measured by the attendant marginal opportunity costs).

To our knowledge, there are no formal theoretical models that address how changes in corporate governance affect firms' green patenting. Our results are consistent with a general interpretation of the "quiet life" argument (Bertrand and Mullainathan 2003). When managers are less exposed to the disciplining role of takeovers - as occurs in the wake of BC legislation - they will focus less on shareholder value and more on private rent extraction; toward this end, such managers reduce activities requiring major organizational changes that would be opposed by existing stakeholders. A significant change in the firm's current pattern of research and development $(\mathrm{R} \& \mathrm{D})$ could well require such changes, since "going green" involves altering the R\&D division while introducing new methods and new research questions. According to an OECD study on the introduction of green management strategies, "the most important factor in preventing firms from taking a more radical approach to eco- 
innovation and aiming for systemic shifts would be that even more progressive businesses remain unconsciously aligned to and locked into conventional business models. Many companies are comfortable with their existing business models and not ready to leverage the crucial systemic changes that are needed for radical innovation."1 In light of such organizational resistance, we remark that a shift in corporate governance toward less shareholder protection will reduce incentives to make the organizational changes necessary to devise and sustain a more ambitious green innovation strategy.

The rest of the paper proceeds as follows. Section 2 describes the data and provides summary statistics. Section 3 illustrates the empirical strategy. Section 4 presents the principal empirical findings and a number of robustness checks. Section 5 illustrates how our main result varies depending on firm and industry characteristics, and Section 6 concludes.

\section{Data and summary statistics}

\subsection{Financial data}

We use firm-level data from the Compustat data set, which contains comprehensive financial information on US publicly traded firms. The time period considered is 1976-1995. We restrict the data set to firms with positive sales and positive book value of assets that are incorporated and headquartered in the United States.

We construct a set of firm-level variables — such as the logarithm of firm sales, of the capital/labor ratio, of R\&D stock, and of firm age as well as an industry-level control, the Herfindahl-Hirschman index (HHI) - to account for the potential effect of market structures on environmental activities (Fernandez-Kranz and Santalo 2010). We compute the HHI using the distribution of firms' revenues in a particular 3-digit SIC (Standard Industrial Classification) industry. Panel A of Table 1 presents summary statistics; see Table A2for a complete description of how each variable was constructed.

\section{[[ INSERT Table 1 about Here ]]}

\footnotetext{
1 "The future of eco-innovation: The role of business models in green transformation," OECD Background Papers (2012).
} 


\subsection{Environmental innovation}

We measure firms' environmental innovation in terms of environment-related patents issued (Jaffe and Palmer 1997; Brunnermeier and Cohen 2003; Carrion-Flores and Innes 2010; Aghion et al. 2011). Patent data come from a data set assembled at the National Bureau of Economic Research (NBER) that contains information on more than 3 million patents granted by the US Patent and Trademark Office (USPTO) and all citations made to these patents starting from 1976 (Hall et al. 2001; Bessen 2009). Using patents—rather than, say, R\&D expenses - allows us to classify innovations according to their technological content, which is crucial for the focus of this study.

Our classification of green patents follows closely that of Carrion-Flores and Innes (2010) and is based on the primary 3-digit patent classification provided by the USPTO. The main technological categories considered are broadly related to air or water pollution, hazardous waste prevention, disposal and control, recycling, and alternative energy. Panel B of Table 1 gives summary statistics for the main innovation variables used in the empirical analysis. A detailed description of the technology classes used to identify green patents is provided in Table A1.

We adopt finer classifications of green innovations as robustness checks. First, we use energy patents (Popp 2002; Popp and Newell 2011). ${ }^{2}$ This approach, which is based on both the main classification and the subclassification of patents, is able to identify renewable technologies as well as new energy sources based on fossil fuels (e.g., fuel cells and coal liquefaction); hence it captures technological efforts both to improve the use of current energy supplies and to develop entirely new sources.

As a second check, we adopt the classification of renewable energy technologies provided by Johnstone et al. (2010). Using the International Patent Classification (IPC), Johnstone and colleagues provide a list of appropriate codes directly related to such renewable technologies as wind, solar, geothermal, ocean, biomass, and waste.

\footnotetext{
${ }^{2}$ See Popp and Newell (2011, Appendix A) for a detailed description of energy patents.
} 


\subsection{Anti-takeover legislation}

Our main corporate governance variable is the adoption of BC laws by thirty US states in the late 1980s. These business combination laws were the most stringent statutes of a wave of laws enacted with the aim of limiting takeover activity among firms incorporated in the legislating states. Specifically, BC laws reduced the threat of hostile takeovers by imposing a 3-5-year moratorium on the transfer of assets from the target to the acquiring company, thus limiting the latter's ability to pay down acquisition debt. Because these laws made it much harder to realize the benefits of takeovers, the consequence was a drastic weakening in the market for corporate control. Given that this market is a powerful mechanism for disciplining managers (Shleifer and Vishny 1997), several empirical works have exploited the passage of $\mathrm{BC}$ laws to demonstrate exogenous worsening in the quality of corporate governance. ${ }^{3}$

\section{[[ INSERT Table 2 about Here ]]}

Table 2 shows the staggered passage of BC laws during the period 1985-1991. Thus our own time window, the period 1976-1995, includes a few years before and after the passage of BC laws. Table 3 shows the number of states and firm-year observations subject to BC laws in our sample. Thirty US states $(68.2 \%$ of states in the sample, accounting for $87.8 \%$ of firm-year observations) passed BC laws; however, fourteen states (13.3\% of states in the sample, $12.2 \%$ of firm-year observations) never passed a BC law.

\section{[[ INSERT Table 3 about Here ]]}

\section{Empirical strategy}

Our main goal is to establish how corporate governance affects firms' environmental innovation. One common approach when addressing this question is to compare the environmental performance of firms with different corporate governance quality. Yet even if we thereby establish a positive association, interpreting it causally-as in saying that better

\footnotetext{
${ }^{3}$ See, for example, Bertrand and Mullainathan (1999; 2003), Francis et al. (2011), and Giroud and Mueller (2010).
} 
corporate governance causes better environmental performance-is complicated by at least two problems. First, the association may be driven by some third (and perhaps unobserved) factor; a leading candidate would be the demands of stakeholders for both good governance and environmental practices. Second, the reverse causality may obtain: perhaps improved environmental performance increases a firm's visibility in the marketplace, which in turn renders managers more accountable. In order to address these complications, we rely on the exogenous variations in governance quality provided by the passage of BC laws.

The advantage of our identification is that the variation in corporate governance was imposed by state-level regulations and is therefore less likely to reflect firms' equilibrium choices. However, there are two potential concerns. The first is that the adoption of BC laws may reflect lobbying by troubled firms seeking protection from hostile takeovers. If that is the case, then the effect we identify in association with the implementation of $\mathrm{BC}$ laws may simply indicate past firm conditions and not a causal effect. To deal with this concern, we draw on existing evidence from legal studies. Romano (1987) finds that most of the lobbying that occurred was on behalf of single firms and that large coalitions of firms played only a minor role in the political processes leading to the adoption of BC laws. Also, the one-on-one nature of lobbying activity reduces the chances that legislation was driven by average corporate outcomes in the legislating states. The second concern is that a firm's decision about where to incorporate is itself affected by BC laws; hence a firm seeking protection from hostile takeovers but incorporated in a state without BC laws may decide to re-incorporate in a state that has such laws. Because Compustat reports only the last (i.e., current) state of incorporation, we cannot tackle this issue directly. However, the literature indicates that changes of incorporation during the period we consider were actually rare (Romano 1993). For instance, Bertrand and Mullainathan (2003) randomly sampled 200 firms from their data set and manually checked how many of them had changed their state of incorporation; only three changes were found-all to Delaware and all several years prior to passage of their respective states' $\mathrm{BC}$ laws.

For the researcher, one important advantage of $\mathrm{BC}$ laws is that they affect firms in their state of incorporation, which often differs from their state of operation. ${ }^{4}$ This

\footnotetext{
${ }^{4}$ In our sample, $64.5 \%$ of firms are incorporated outside their state of operations.
} 
discrepancy allows us to compare, within a given state and industry, the environmental activities of firms that were affected by worse governance (i.e., were incorporated in a $\mathrm{BC}$ state) while using as a control group those firms that were not exposed to governance changes (i.e., were incorporated in a state that passed BC laws either later or never).

\section{[[ INSERT Figure 1 about Here ]]}

An illustration of our methodology is presented in Figure 1, which compares the average green patenting activity of firms incorporated in Massachusetts and California. Whereas the former (treatment group) experienced a worsening in corporate governance due to passage of a BC law in 1989, the latter (control group) experienced no such change because California did not pass any $\mathrm{BC}$ legislation. If we focus on the pre-BC years then it is clear that, although Massachusetts incorporations patented more green innovations on average, the slightly upward trend did not differ much from California incorporations. Yet focusing on post-BC years reveals a sharp decline in the green patenting activity of Massachusetts incorporations even as California incorporations seem to follow the existing trends. To establish the statistical significance of this change for Massachusetts, we estimate a simple difference-in-differences (DiD) model: the dependent variable is the state-year average of the logarithm of cite-weighted green patent counts; and the explanatory variables are dummies for Massachusetts and post-BC passage as well as their interaction. The coefficient reported in Table 4 for the interaction term indicates that, relative to California incorporations, firms incorporated in Massachusetts experienced a significant drop in green patenting following the passage of BC laws.

\section{[[ INSERT Table 4 about Here ]]}

Our main identification generalizes this example to all states and $\mathrm{BC}$ passages over the years. Specifically, we estimate the following DiD model:

$$
Y_{i k t}=\alpha_{i}+\alpha_{t}+\beta\left(\mathrm{BC}_{k t}\right)+\gamma^{\prime} X_{i k t-1}+e_{i k t}
$$


Here $Y_{i k t}$ measures, at time $t$, the green patenting activity of firm $i$ incorporated in state $k$; $\mathrm{BC}_{k t}$ is a dummy variable set equal to 1 if a firm is incorporated in a state that has passed a BC law by time $t$ (treatment group) and to 0 otherwise (control group). Hence the coefficient $\beta$ measures the effect of $\mathrm{BC}$ law passage on firms' green patenting activity relative to firms incorporated in states that passed BC laws later in time (or that never passed a BC law).

Given that firms incorporated in $\mathrm{BC}$ states are different from those incorporated in states that never passed BC laws (Giroud and Mueller 2010), it is important to include a comprehensive set of controls. In particular, $\alpha_{i}$ and $\alpha_{t}$ represent (respectively) firm and year fixed effects, which are included to account for common shocks (e.g., the energy crises of the 1970s) that might affect environmental activities and for unobserved heterogeneity across firms that is invariant over time. The term $X_{i k t-1}$ is a vector of controls that includes (depending on the specification) the logarithm of firm sales, of the capital/labor ratio, of R\&D stock, and of firm age in addition to the HHI. Controls are lagged by one year to preclude confounding by potentially simultaneous effects of BC laws. Finally, we include as controls the headquarters state and the 3-digit industry linear trends; the latter are computed as yearly averages of the dependent variable excluding the firm in question. Finally, $e_{i k t}$ denotes the residuals, which we estimate while clustering by the state of incorporation. This procedure accounts for arbitrary correlations of residuals across different firms in a given year and state of incorporation, across different firms in a given state of incorporation over time, and over different years for a given firm (Giroud and Mueller 2010).

\section{Results}

\subsection{Main result}

This section presents our main result in terms of different proxies for green patenting. In column [1] of Table 5, the dependent variable is the logarithm of 1 plus cite-weighted green patent counts. In column [2], the dependent variable is an indicator set equal to 1 only if a firm reports (in a given year) at least one environment-related patent; column [3] uses the same indicator as column [2] but restricts the analysis to patenting firms. Results indicate that exposure to $\mathrm{BC}$ laws has a negative and statistically significant effect on green patenting. 


\section{[[ INSERT Table 5 about Here ]]}

As Atanassov (2013) shows, BC laws have a negative effect on firms' overall patenting activity. It is therefore possible that our results are driven by a generic reduction in corporate patents. We mitigate this concern by using, in column [4] of Table 5, the ratio of green patents to the total number of patents. The reported values demonstrate that firms subject to BC laws experienced a drop in green patents relative to their overall innovation effort. We confirm this result by using the ratio of (cite-weighted) green to total patent counts (column [5]), which is adopted as our main dependent variable throughout the empirical analysis. Using this ratio of cite-weighted patent counts is necessary to account not only for the difference in number of patents but also for their technological importance (as reflected by the future citations received). Following the passage of $\mathrm{BC}$ laws, firms incorporated in legislating states reduced their green patenting activity by 3.9 percentage points. Given that the average ratio of cite-weighted green patents to total patents is $25 \%$, the reductions amount to approximately $15 \%$ of the average green innovation and are therefore economically relevant.

\subsection{Robustness checks}

The difference-in-differences setup raises a number of questions about the validity of our findings. These questions are addressed in this section.

First, we take into account that an ordinary least-square (OLS) regression may be inappropriate because our favored dependent variable (column [5] in Table 5) is a proportion that involves zeros (corresponding to firms that do not patent any green innovation). Column [2] of Table 6 reports the results obtained when using a pooled fractional nonlinear procedure estimated via quasi-maximum likelihood (QML) techniques (as proposed by Papke and Wooldridge 1996), including indicator variables for state and 3-digit SIC industry. ${ }^{5}$

\footnotetext{
$5 \mathrm{We}$ also extend this model to a panel setting by using a fractional probit model with heteroskedasticity-robust standard errors, as in Papke and Wooldridge (2008). Our results are largely robust to adopting this alternative procedure, but the model has some difficulties with unbalanced data.
} 


\section{[[ INSERT Table 6 about Here ]]}

Second, "green" projects can be defined in several ways; yet we show that our results do not depend on the particular categorization used. For this demonstration we employ several alternative dependent variables. In column [2] of Table 6, we use the ratio of patents for new energy technologies (Popp 2002; Popp and Newell 2011) to a firm's total patents, and in column [3] we use the ratio of patents for renewable technologies (Johnstone et al. 2010) to a firm's total patents. Each of these alternative specifications yields a significant and negative effect of BC laws on the ratio of green projects-just as in the original specification.

Third, we are concerned that the results may be driven by specific states. To ensure that our findings are not driven by influential states that report the highest innovation activity, we run the regression while excluding firms headquartered in California (column [4] of Table 6). Because most firms are incorporated in Delaware, we also ensure-via an analogous exclusion in column [5] of the table - that our results are not driven by Delaware incorporations. Finally, in column [6] we exclude states that never passed BC legislation and thus use only the staggered passage of BC laws when constructing the control group. Our main finding is robust to all of these exclusions. Moreover, we show that our results are robust also to restricting the analysis to manufacturing (column [7] of Table 6) - the sector that is viewed as the main source of toxic emissions ${ }^{6}$ and that also accounts for the majority of patenting activity (Scherer 1983; Balasubramanian and Sivadasan 2011) — and to extending the sample to the year 2000 (column [8]).

It could be argued that the passage of BC laws mirrors a state's policy of being less favorable to green innovation. From this perspective, the key is that passage of a BC law might be correlated with the release of some other information about how states in general provide incentives to engage in green innovation. The possibly confounding effect of this

\footnotetext{
${ }^{6}$ However, manufacturing activities are extremely heterogeneous in terms of pollution emissions, and they occur in sectors with relatively high (e.g., chemicals) and low (e.g., apparel) emission levels. In unreported analyses, our findings are substantially unchanged when restricted to either the subsample of the most pollution-intensive industries or the subsample of all other industries. We follow existing studies (e.g., Keller and Levinson 2002) in classifying, as pollution-intensive industries: pulp and paper (SIC 26), chemicals (SIC 28), petroleum (SIC 29), stone clay and glass (SIC 32), primary metals (SIC 33), fabricated metals (SIC 34), and transportation equipment (SIC 37).
} 
dynamic is minimized by the nature of our corporate governance shock: whereas BC laws affected firms depending on their state of incorporation, a state's general policy toward green innovation is likely to matter to the firm's headquarters, which is often located elsewhere than in the state of incorporation. That discrepancy allows us to control for state green policies.

In unreported analyses, we confirm our results in several ways. For example, we restrict the analysis to firms that remain in the data set for at least four (or eight, or twelve) years in order to mitigate the effects of entry and exit. Another concern arises because we cannot identify the month in which a BC law was passed; it may therefore be inappropriate to consider as "post-BC period" the observations for states that passed a BC law at the end of the year. To address this possibility, we drop those firm-year observations corresponding to the year of BC passage. We also allow for heterogeneous time and state effects by interacting all the covariates with year and treatment-state dummies. Equation $(\dagger)$ contains one-year lagged controls; we replicate our results when instead using two-year lags or contemporaneous controls. Finally, we also confirm that our results are robust to alternative procedures of estimating the standard errors-for example, clustering at the firm level or using blockbootstrap methods (as proposed in Bertrand et al. 2004) with 100 replications. In sum, our main finding (that the introduction of BC laws reduced firms' green innovation activities) is robust to a wide variety of alternative specifications that accommodate several different empirical concerns.

\subsection{Dynamics}

We test for dynamic effects by replacing the binary indicator variable for the passage (or not) of BC laws with a set of lags and leads around BC law passage. The omitted group then consists of observations from the third year (or earlier) prior to $\mathrm{BC}$ passage and from never$\mathrm{BC}$ states. The results, which are reported in Table 7, establish that the negative effect of $\mathrm{BC}$ laws is statistically and economically insignificant before the actual year of BC law passage. This finding is of special importance because it shows that our finding is not driven by the pre-treatment performance characteristics of firms (as might occur, e.g., if struggling firms that sought protection in BC laws were also less successful in green innovation). The BC law 
coefficient increases from the year of passage onward, and it is statistically significant (at the $5 \%$ level) as soon as the second year after BC law passage.

\section{[[ INSERT Table 7 about Here ]]}

\section{Governance and economic variations}

In this section we investigate variations in the effect of BC laws on green innovation. We begin by documenting that the reduction in green patents is shaped by the presence of alternative governance mechanisms within the firm. To test this hypothesis, we use the equity share held by institutional investors as a proxy for firm-level shareholders' power. We draw the annual data on institutional investor holdings from SEC 13 filings recorded in the Thompson Financial CDA/Spectrum database, ${ }^{7}$ and we construct an indicator variable set equal to 1 or 0 according as whether the firm has a large (above-median) or small (belowmedian) fraction of institutional ownership; this variable is then interacted with the dummy for BC law.

Column [1] of Table 8 reports the results of this exercise. We observe that the effect is present both for firms with a high and for firms with a low level of institutional ownership. That being said, the coefficient for high level of institutional ownership is nearly $25 \%$ larger and is statistically significant at the $5 \%$ level. This finding is consistent with the argument that, by monitoring managers, large institutional owners mitigate the negative effect of $\mathrm{BC}$ laws (worse governance) on green innovation.

\section{[[ INSERT Table 8 about Here ]]}

We now discuss how economic incentives affected the decline in green patents following passage of BC laws. A recent literature (see e.g. Acemoglu et al. 2011; Aghion et al. 2011) has argued that innovation activities often exhibit path dependency. When firms have a large stock of innovation projects, the marginal cost of new products is reduced by

\footnotetext{
${ }^{7}$ All institutional investors with more than $\$ 100$ million of securities under management must report their holdings to the Securities and Exchange Commission (SEC) on Form 13F; they must also disclose all common stock positions that exceed either 10,000 shares or $\$ 200,000$.
} 
using such lasting resources as knowledge or technology from previous projects. The idea is that "firms build on their existing stock of technology-specific knowledge to develop new innovations, which in turn can lead to technological lock-in" (Aghion et al. 2011). Accordingly, the existing stock of green patents should have a positive effect on the propensity to patent new green innovations. Applying this argument to our context, we claim that it is relatively easier for worse-governed firms to reduce green innovations when the firm is not constrained by the technological lock-in induced by past innovation decisions. To test this prediction, we construct the stock of green patents using the perpetual inventory method (Cockburn and Griliches 1988; Peri 2005) and a 15\% depreciation rate. ${ }^{8}$ We interact the indicator of worse governance with a dummy set equal to 1 if the firm has a large (abovemedian) stock or to 0 if it has a small (below-median) stock of green patents. In line with the notion of technological lock-in, the values reported in column [2] of Table 8 indicate that, compared to firms with a small stock of green patents, the $R \& D$ of firms with large stock are less affected by BC laws. The considerable difference between the two coefficients suggests that firms are partly locked in to past technologies and that this effect influences the response of firms to exogenous variations in corporate governance.

Next we argue that the opportunity cost of switching from green to nongreen innovation activities is higher for firms that operate in industries highly dependent on energy resources. For such industries, we predict that BC laws will have less of a negative effect on green patents. In order to test this hypothesis, we compute an industry-level measure of energy dependence using data from the NBER manufacturing data set. In particular, we take the ratio of energy expenses (cost of electrics and fuels) to the total value added. Then we classify industries as being strongly (above-median) or weakly (below-median) dependent on energy and interact this indicator with the BC law dummy. The results, reported in column [3] of Table 8 , show that $\mathrm{BC}$ law passage reduces the proportion of green patents more in industries with low energy dependence. ${ }^{9}$ Although insignificant statistically, the difference between industries with low and high energy dependence suggests that $\mathrm{BC}$ laws did have

\footnotetext{
${ }^{8}$ To account for heterogeneity in the value of patent stock, in an unreported robustness check we use the stock of green patents weighted by citations received in subsequent patents.

${ }^{9}$ This analysis is limited to firms in the SIC codes $2000-4000$ because these are the only ones covered by the NBER manufacturing data set.
} 
some impact on the green innovation activities of firms that operate in industries characterized by less energy dependence.

Another variation in firms' opportunity costs of dropping green projects is the stringency of environmental regulations in the state where the firm is headquartered. We claim that the cost of lowering environmental innovation should be higher in states with stringent pollution regulations. To test this argument, we adopt the index computed by Levinson (2001) and Keller and Levinson (2002), who use data from the Pollution Abatement Costs and Expenditures (PACE) survey to quantify industry-adjusted pollution abatement costs in 48 US states. ${ }^{10}$ A higher value of this index corresponds to a more stringent regulation of the state's environment. We interact the BC law dummy with an indicator set equal to 1 or 0 according as whether the firm's state of headquarters has a high (abovemedian) or low (below-median) pollution abatement cost index. ${ }^{11}$ As shown in column [4] of Table 8 , the negative effect of worse governance is significant and economically greater when the firm operates in a state where pollution abatement costs are low. In other words, a higher cost of complying with pollution regulations lessens the drop in environmental innovation caused by the managerial slack after passage of BC laws.

In short, Table 8 provides evidence suggesting that variations in the opportunity costs of reducing green innovations affected the drop in innovation projects induced by passage of BC laws.

\section{Concluding remarks}

Recent research suggests that managerial and corporate governance characteristics play an important role in determining corporate policies. We contribute to this research by establishing the causal effect of corporate governance on firms' environmental innovation. Our results indicate that worse-governed firms exhibit less environmental innovation: when the quality of corporate governance is reduced by anti-takeover laws, the result is a reduction of $15 \%$ (on average) in green patenting. We also show that the magnitude of this effect is shaped by the opportunity costs of reducing green innovation. These findings are consistent

\footnotetext{
${ }^{10}$ See http://www.census.gov/econ/overview/mu1100.html for more details on the PACE survey.

${ }^{11}$ We also exclude 1987 because of missing data for that year in the original survey.
} 
with a "quiet life" explanation, according to which the managers of worse-governed firms extract private benefits by avoiding activities that are cognitively challenging or systemically disruptive.

What are the welfare implications of our results? Popp and Newell (2011) offer two arguments suggesting that alternative energy innovations are among the projects with highest social return. First, there is comparatively less amount of research available on alternative energy than in other fields, which increases the potential for knowledge spillovers. Second, alternative energy innovations may affect a broader array of industries than do traditional innovations; hence they have more potential to constitute general purpose technologies (GPTs). These arguments imply that worse governance-by reducing environmental innovation - is detrimental for society at large. 


\section{References}

Acemoglu D., Aghion P., Bursztyn L. and Hemous D. (2011) “The Environment and Directed Technical Change", American Economic Review, forthcoming.

Aghion P., Dechezleoretre A., Hemous D., Martin R. and Van Reenen J. (2011) "Carbon Taxes, Path Dependency and Directed Technical Change: Evidence from the Auto Industry", Working Paper.

Atanassov J. (2013) "Do Hostile Takeovers Stifle Innovation? Evidence from Antitakeover Legislation and Corporate Patenting", Journal of Finance, forthcoming.

Balasubramanian N. and Sivadasan J. (2011) "What Happens when Firms Patent: New Evidence from US Economic Census Data", Review of Economics and Statistics, forthcoming.

Bertrand M., Duflo E. and Mullainathan S. (2004) "How Much Should we Trust Differencein-Differences Estimates?”, Quarterly Journal of Economics 119, 249-275.

Bertrand M. and Mullainathan S. (1999) "Is There Discretion in Wage Setting? A Test Using Takeover Legislation", Rand Journal of Economics 30, 535-554.

Bertrand M. and Mullainathan S. (2003) "Enjoying the Quiet Life? Corporate Governance and Managerial Preferences”, Journal of Political Economy 111, 1043-1075.

Bessen J. (2009) "NBER PDP Project User Documentation: Matching Patent Data to Compustat Firms", available at: http://www.nber.org/ jbessen/matchdoc.pdf

Bloom N., Genakos C., Martin R. and Sadun R. (2010) "Modern Management: Good for the Environment or Just Hot Air?”, Economic Journal 120, 551-572.

Brunnermeier S. and Cohen M (2003) "Determinants of Environmental Innovation in U.S. Manufacturing Industries", Journal of Environmental Economics and Management $45,278-293$.

Carrion-Flores C. and Innes R. (2010) "Environmental Innovation and Environmental Performance", Journal of Environmental Economics and Management 59, 27-42.

Cockburn I. and Griliches Z. (1988) "Industry Effects and Appropriability Measures in the Stock Market's Valuation of R\&D and Patents", American Economic Review 78, 41923. 
Cole M.A., Elliot R.J.R. and Strobl E. (2007) "The Environmental Performance of Firms: The Role of Foreign Ownership, Training, and Experience", Ecological Economics 65, 538-546.

De Canio S. and Watkins W. (1998) "Investment in Energy Efficiency: Do the Characteristics of Firms Matter?", Review of Economics and Statistics 80, 95-107.

Fernandez-Kranz D. and Santalo J. (2010) "When Necessity Becomes a Virtue: The Effect of Product Market Competition on Corporate Social Responsibility", Journal of Economics \& Management Strategy 19, 453-487.

Francis B.B., Hasan I., Kose J. and Song L. (2011) "Corporate Governance and Dividend Payout Policy: A Test Using Antitakeover Legislation", Financial Management 40, 83-112.

Giroud X. and Mueller H. (2010) "Does Corporate Governance Matter in Competitive Industries?”, Journal of Financial Economics 95, 312-331.

Hall B.H., Jaffe A. and Trajtenberg M. (2001) "The NBER Patent Citation Data File: Lessons, Insights and Methodological Tools”, Working Paper 8498, National Bureau of Economic Research.

Hall B.H., Jaffe A. and Trajtenberg M. (2005) "Market Value and Patent Citations", RAND Journal of Economics 36, 16-38.

Jaffe A., Newell R. and Stavins R.N. (2002) “Technological Change and the Environment", Environmental and Resource Economics 22, 41-69.

Jaffe A. and Palmer K. (1997) "Environmental Regulation and Innovation: A Panel Data Study", Review of Economics and Statistics 79(4), 610-619.

Johnstone N., Hascic I. and Popp D. (2010) "Renewable Energy Policy and Technological Innovation: Evidence from Patent Counts", Environmental and Resource Economics $45,133-155$.

Keller W. and Levinson A. (2002) "Pollution Abatement Costs and Foreign Direct Investment Inflows to U.S. States", Review of Economics and Statistics 84, 691- 703.

Kock C.J., Santalo J. and Diestre L. (2011) "Corporate Governance and the Environment: What Type of Governance Creates Greener Companies?", Journal of Management Studies, forthcoming. 
Levinson A. (2001) “An Industry-Adjusted Index of State Environmental Compliance Costs”, in Metcalf G. and Carraro C. (eds.), Behavioral and Distributional Effects of Environmental Policy, University of Chicago Press.

Martin R. (2010) "Why is the U.S. so Energy Intensive? Evidence from US Multinationals in the UK”, CEP Discussion Paper 965.

Papke L.E. and Wooldridge J. (1996) "Econometric Methods for Fractional Response Variables with an Application to 401(k) Plan Participation Rates”, Journal of Applied Econometrics 11, 619-632.

Papke L.E. and Wooldridge J. (2008) "Panel Data Methods for Fractional Response Variables with an Application to Test Pass Rates", Journal of Econometrics 145, 121-133.

Peri G. (2005) "Determinants of Knowledge Flows and their Effects on Innovation", Review of Economics and Statistics 87, 308-322.

Popp D. (2002) "Induced Innovation and Energy Prices", American Economic Review 92, 160-180.

Popp D. and Newell R. (2011) "Where Does Energy R\&D Come From? Examining Crowding Out from Energy R\&D”, Energy Economics, forthcoming.

Romano R. (1987) “The Political Economy of Takeover Statutes”, Virginia Law Review 73, 111-199.

Romano R. (1993) "Competition for Corporate Charters and the Lesson of Takeover Statutes", Fordham Law Review 61, 843-64.

Scherer F.M. (1983)" The Propensity to Patent", International Journal of Industrial Organization 1, 226-237.

Shleifer A. and Vishny R.W. (1997) “A Survey on Corporate Governance”, Journal of Finance 52, 737-783. 


\section{Figure 1.}

\section{Green patenting and BC laws: An example}

This graph plots the average logarithm of 1 plus cite-weighted green patent counts for firms incorporated in California and Massachusetts in the years before and after 1989. Massachusetts passed BC legislation in 1989; California never passed BC legislation.

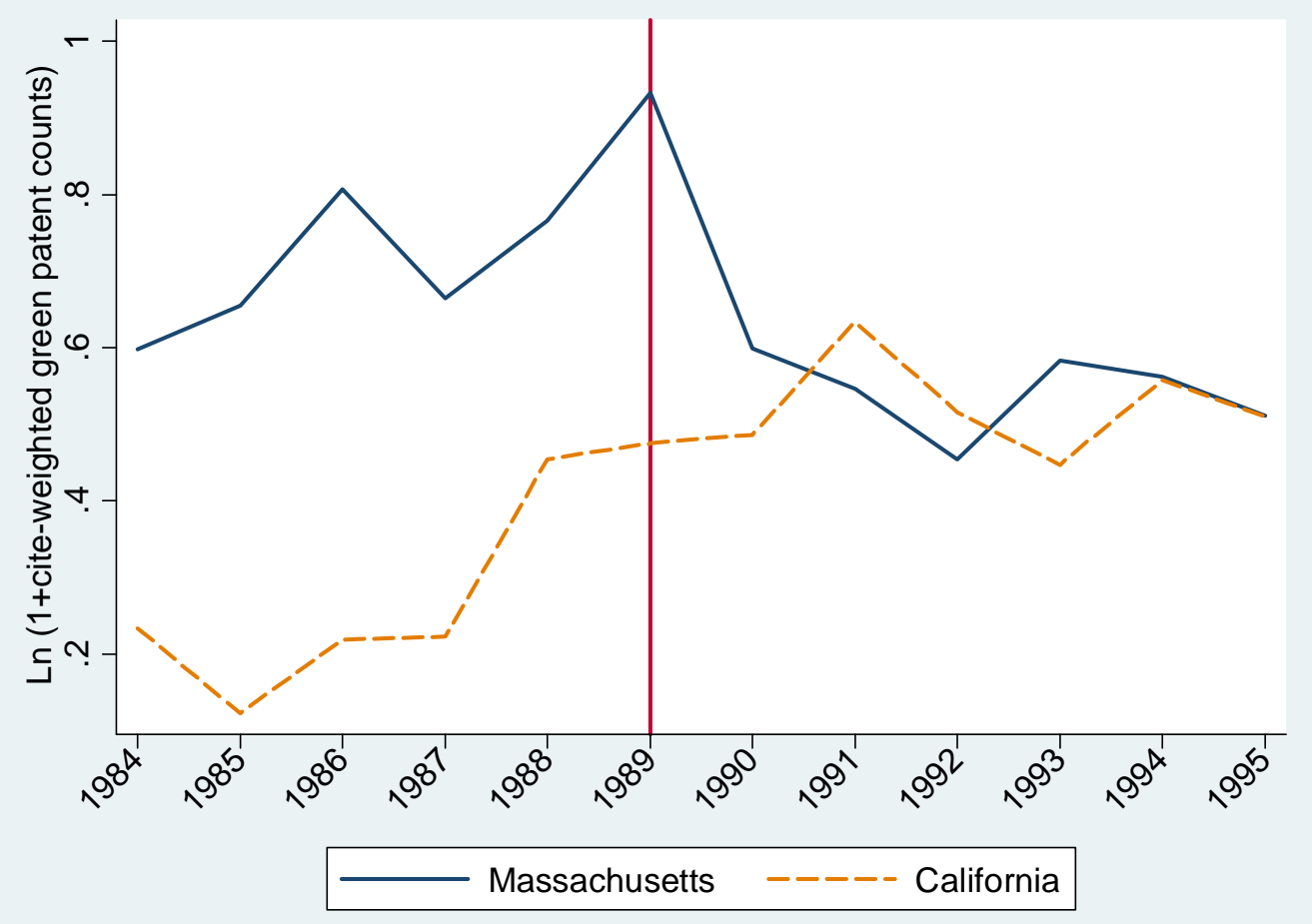


Table 1.

\section{Summary statistics}

This table provides summary statistics for main variables used in the empirical analysis. A complete description of each variable is provided in Table A2

\begin{tabular}{lcccc}
\hline \hline & $\begin{array}{c}\text { Number of } \\
\text { observations }\end{array}$ & Mean & $\begin{array}{c}\text { Standard } \\
\text { deviation }\end{array}$ & Median \\
\cline { 2 - 5 } & {$[1]$} & {$[2]$} & {$[3]$} & {$[4]$} \\
\hline Ln(Sales) & 43,573 & 4.077 & 2.429 & 4.021 \\
$\operatorname{Ln}(K / L)$ & 42,951 & 2.843 & 0.987 & 2.839 \\
Ln(Age) & 43,777 & 2.449 & 0.802 & 2.485 \\
HHI & 43,654 & 0.174 & 0.115 & 0.141 \\
Patent counts & 31,687 & 10.347 & 42.652 & 1 \\
Green patent counts & 31,687 & 2.417 & 9.856 & 0 \\
Green patent to all patent counts & 13,429 & 0.253 & 0.323 & 0.1 \\
Cite-weighted patent counts & 31,687 & 167.487 & 836.445 & 1.058 \\
Cite-weighted green patent counts & 31,687 & 32.756 & 144.639 & 0 \\
Cite-weighted green patent to all patent counts & 13,388 & 0.251 & 0.337 & 0.052 \\
\hline \hline
\end{tabular}




\section{Table 2.}

\section{Business combination laws by state}

This table illustrates the passage of business combination (BC) laws in the US states. Those states that have never passed $\mathrm{BC}$ legislation are listed at the bottom of the table.

\begin{tabular}{lc}
\hline \hline & Law \\
State & passage \\
\hline New York & 1985 \\
Indiana, Missouri, New Jersey & 1986 \\
Arizona, Kentucky, Minnesota, Washington, Wisconsin & 1987 \\
Delaware, Georgia, Idaho, Maine, Nebraska, South Carolina, Tennessee, Virginia & 1988 \\
Connecticut, Illinois, Kansas, Maryland, Massachusetts, Michigan, Pennsylvania, & 1989 \\
Wyoming & \\
Ohio, Rhode Island, South Dakota & 1990 \\
Nevada, Oklahoma & 1991 \\
Alabama, Alaska, Arkansas, California, Colorado, District of Columbia, Florida, Hawaii, & Never \\
Iowa, Louisiana, Mississippi, Montana, New Hampshire, New Mexico, North Carolina, & \\
North Dakota, Oregon, Texas, Utah, Vermont, West Virginia & \\
\hline \hline
\end{tabular}

\section{Table 3.} Distribution of states and firms

This table reports the distribution of states that did and did not pass $\mathrm{BC}$ legislation as well as the number of firms incorporated in these states.

\begin{tabular}{lcc}
\hline \hline & & Never \\
& BC & BC \\
\cline { 2 - 3 } & {$[1]$} & {$[2]$} \\
\hline Number of states (\%) & $30(65 \%)$ & $16(35 \%)$ \\
Number of firms (\%) & $2,786(87 \%)$ & $422(13 \%)$ \\
\hline \hline
\end{tabular}




\section{Table 4.}

\section{Green patenting and BC laws: DiD}

This table presents the result of an OLS regression in which the dependent variable is the state-year average of the logarithm of 1 plus cite-weighted green patent counts. The explanatory variables are: (1) a dummy set equal to 1 only for the years 1989 onward; (2) a dummy set equal to 1 for firms operating in Massachusetts; and (3) the interaction between them. Robust standard errors are reported in parentheses. $*, * *$, and $* * *$ denotes significance at the $10 \%$, $5 \%$, and $1 \%$, respectively.

Dependent variable: $\mathrm{Ln}(1+$ Cite-weighted green patent counts)

\begin{tabular}{lc}
\hline Post-BC passage & $0.2675^{* * *}$ \\
& $(0.0587)$ \\
Massachusetts & $0.4474^{* * *}$ \\
& $(0.0656)$ \\
Massachusetts $\times$ Post-BC passage & $-0.3671^{* * *}$ \\
& $(0.0916)$ \\
\hline Number of observations & 24 \\
\hline \hline
\end{tabular}




\section{Table 5.}

\section{Main regressions}

This table presents results obtained from OLS regressions. The dependent variable in column [1] is the logarithm of 1 plus cite-weighted green patent counts; in column [2], an indicator set equal to 1 if the firm reports at least one green patent in a given year (and to 0 otherwise); in column [3], an indicator set equal to 1 if the firm reports at least one green patent in a given year (and to 0 otherwise) conditional on being a patenting firm; in column [4], the ratio of green to total patent counts; in column [5], the ratio of cite-weighted green to total patent counts. Each regression includes firm fixed effects, year dummies, and headquarters' state in addition to industry linear trends computed as annual averages of the dependent variable (after excluding the firm in question). Each regression also controls for the logarithm of sales, of the capital/labor ratio, of the R\&D stock, and of firm age as well as the HHI and its square. Each control is lagged by one year. The construction of each variable is described in Table A2. Standard errors (in parentheses) are clustered by state of incorporation. * $* *$, and *** denote (respectively) significance at the $10 \%, 5 \%$, and $1 \%$ level.

\begin{tabular}{llllll}
\hline \hline Dependent variable: & $\begin{array}{l}\text { Ln }(1+\text { green } \\
\text { patent cites })\end{array}$ & $\begin{array}{l}\text { At least one } \\
\text { green patent }\end{array}$ & $\begin{array}{l}\text { At least one } \\
\text { green patent } \mid \\
\text { patents }>0\end{array}$ & $\begin{array}{l}\text { Green patents } \\
\text { to all patents }\end{array}$ & $\begin{array}{l}\text { Cite-weighted } \\
\text { green patents } \\
\text { to all patents }\end{array}$ \\
\cline { 2 - 6 } & $(1)$ & $(2)$ & $(3)$ & $(4)$ & $(5)$ \\
\hline BC & $-0.0477^{*}$ & $-0.0181^{* *}$ & $-0.0601^{* *}$ & $-0.0327^{* *}$ & $-0.0385^{* *}$ \\
& $(0.0276)$ & $(0.0082)$ & $(0.0248)$ & $(0.0153)$ & $(0.0164)$ \\
Ln sale & $0.0739^{* * *}$ & $0.0216^{* * *}$ & $0.0398^{* * *}$ & -0.0014 & -0.0022 \\
& $(0.0166)$ & $(0.0038)$ & $(0.0084)$ & $(0.0055)$ & $(0.0050)$ \\
Ln $(\mathrm{K} / \mathrm{L})$ & 0.0065 & 0.0019 & 0.0043 & $0.0099^{*}$ & $0.0159^{* * *}$ \\
& $(0.0065)$ & $(0.0022)$ & $(0.0099)$ & $(0.0052)$ & $(0.0057)$ \\
HHI & $0.6561^{* * *}$ & 0.0893 & 0.0792 & $-0.1930^{* *}$ & $-0.2132^{*}$ \\
& $(0.1966)$ & $(0.0644)$ & $(0.1952)$ & $(0.0824)$ & $(0.1111)$ \\
HHI ${ }^{2}$ & $-0.5910^{*}$ & -0.0436 & 0.0748 & 0.1587 & 0.1379 \\
& $(0.3182)$ & $(0.1016)$ & $(0.3606)$ & $(0.1769)$ & $(0.1957)$ \\
Ln age & $-0.0820^{* * *}$ & -0.0065 & -0.0092 & -0.0083 & -0.0069 \\
& $(0.0267)$ & $(0.0071)$ & $(0.0132)$ & $(0.0090)$ & $(0.0098)$ \\
Ln R\&D stock & $0.2787^{* * *}$ & $0.0641^{* * *}$ & $0.0689^{* * *}$ & -0.0052 & -0.0064 \\
& $(0.0209)$ & $(0.0043)$ & $(0.0078)$ & $(0.0068)$ & $(0.0069)$ \\
\hline Year fixed effects & Yes & Yes & Yes & Yes & Yes \\
Firm fixed effects & Yes & Yes & Yes & Yes & Yes \\
State and industry trends & Yes & Yes & Yes & Yes & Yes \\
Number of observations & 31,662 & 31,195 & 13,268 & 13,425 & 13,292 \\
\hline \hline
\end{tabular}


Table 6.

\section{Robustness}

This table presents results from various specifications. In column [1] we estimate the model in column [5] of Table 5 using a pooled fractional logit model that includes state and 3-digit SIC industry fixed effects rather than firm fixed effects. Column [2] reports OLS estimates using the ratio of energy patent counts to total patent counts, and column [3] reports OLS estimates using the ratio of renewable-related patent counts to total patent counts. In column [4] we exclude firms headquartered in California, and in column [5] we exclude firms incorporated in Delaware. Column [6] excludes firms incorporated in states that never passed a BC law; column [7] includes only those firms operating in the manufacturing sector (SIC from 2000 to 4000), and column [8] extends the sample period through 1999. Unless otherwise indicated, each regression includes the controls used in column [5] of Table 5. The construction of each variable is described in Table A2. Standard errors (in parentheses) are clustered by state of incorporation. $*$ and ${ }^{* *}$ denote (respectively) significance at the $10 \%$ and $5 \%$ level.

\begin{tabular}{|c|c|c|c|c|c|c|c|c|}
\hline & $\begin{array}{c}\text { Pooled } \\
\text { fractional } \\
\text { logit } \\
\end{array}$ & $\begin{array}{c}\text { Energy patent } \\
\text { to all patent } \\
\text { counts }\end{array}$ & $\begin{array}{c}\text { Renewable } \\
\text { patent to all } \\
\text { patent counts }\end{array}$ & $\begin{array}{l}\text { Excluding } \\
\text { California } \\
\end{array}$ & $\begin{array}{l}\text { Excluding } \\
\text { Delaware }\end{array}$ & $\begin{array}{c}\text { Excluding } \\
\text { never-BC } \\
\text { states }\end{array}$ & $\begin{array}{l}\text { Manufacturing } \\
\text { industries only }\end{array}$ & $\begin{array}{c}\text { Time period } \\
\text { until } 2000\end{array}$ \\
\hline & [1] & {$[2]$} & [3] & [4] & [5] & [6] & {$[7]$} & {$[8]$} \\
\hline $\mathrm{BC}$ & $\begin{array}{c}-0.2121 * * \\
(0.0895)\end{array}$ & $\begin{array}{c}-0.0123^{*} \\
(0.0062)\end{array}$ & $\begin{array}{c}-0.0017 * * \\
(0.0007)\end{array}$ & $\begin{array}{c}-0.0263 * * \\
(0.0122)\end{array}$ & $\begin{array}{c}-0.0335^{*} \\
(0.0178)\end{array}$ & $\begin{array}{c}-0.0283 * * \\
(0.0138)\end{array}$ & $\begin{array}{c}-0.0413 * * \\
(0.0168)\end{array}$ & $\begin{array}{c}-0.0328 * \\
(0.0178)\end{array}$ \\
\hline Year fixed effects & Yes & Yes & Yes & Yes & Yes & Yes & Yes & Yes \\
\hline State and industry trends & Yes & Yes & Yes & Yes & Yes & Yes & Yes & Yes \\
\hline Controls & Yes & Yes & Yes & Yes & Yes & Yes & Yes & Yes \\
\hline Number of observations & 13,292 & 13,235 & 13,235 & 11,131 & 6,060 & 12,282 & 11,931 & 18,677 \\
\hline
\end{tabular}




\section{Table 7. \\ Dynamic effects}

This table presents results obtained from OLS regressions. The dependent variable is the ratio of cite-weighted green patent counts to total citeweighted patent counts. The BC dummy treatment used in previous tables is replaced with a set of dummies for the years around passage of the $\mathrm{BC}$ legislation. Each regression includes the controls used in column [5] of Table 5. Standard errors (in parentheses) are clustered by state of incorporation. $* *$ denotes significance at the $5 \%$ level

Dependent variable: Cite-weighted green patents to all patents

\begin{tabular}{lc}
\cline { 2 - 2 } & {$[1]$} \\
\hline $\mathrm{BC}(t=-2,-1)$ & -0.0106 \\
$\mathrm{BC}(t=0)$ & $(0.0215)$ \\
& -0.0416 \\
$\mathrm{BC}(t=1)$ & $(0.0289)$ \\
& -0.0486 \\
$\mathrm{BC}(t=2+)$ & $(0.0318)$ \\
& $-0.0594^{* *}$ \\
Year fixed effects & $(0.0260)$ \\
Firm fixed effects & Yes \\
State and industry trends & Yes \\
Controls & Yes \\
Number of observations & Yes \\
\hline \hline
\end{tabular}




\section{Table 8.}

\section{Economic and governance variations}

This table presents results obtained from OLS regressions. The dependent variable is the ratio of cite-weighted green patent counts to total cite-weighted patent counts. High (resp. low) institutional ownership is a dummy set equal to 1 (resp. 0) if the firm has a share of institutional ownership above (resp. below) the median value. Small (large) stock of green patents is a dummy set equal to $1(0)$ if the firm has a stock of cite-weighted green patents above (below) the median value. High (low) pollution abatement costs is a dummy set equal to 1 (0) if the firm operates in a state that is above (below) the median abatement cost index constructed by Levinson (2001) and Keller and Levinson (2002). High (low) energy dependence is a dummy set equal to 1 (0) if the firm operates in an industry above (below) the median threshold of an energy dependence index, for which we use the NBER manufacturing data set to compute the ratio of energy expenses (cost of electric and fuels) to total value added. Each regression includes the controls used in column [5] of Table 5. Standard errors (in parentheses) are clustered by state of incorporation. *, **, and $* * *$ denote (respectively) significance at the $10 \%, 5 \%$, and $1 \%$ level.

Dependent variable: Cite-weighted green patents to all patents

\begin{tabular}{|c|c|c|c|c|}
\hline & \multirow[b]{2}{*}[1]{} & & & \\
\hline & & [2] & [3] & [4] \\
\hline $\mathrm{BC} \times$ Low institutional ownership & $\begin{array}{c}-0.0443 * * \\
(0.0167)\end{array}$ & & & \\
\hline $\mathrm{BC} \times$ High institutional ownership & $\begin{array}{c}-0.0334 * \\
(0.0181)\end{array}$ & & & \\
\hline $\mathrm{BC} \times$ Small stock of green patents & & $\begin{array}{c}-0.0867 * * * \\
(0.0173)\end{array}$ & & \\
\hline $\mathrm{BC} \times$ Large stock of green patents & & $\begin{array}{l}-0.0068 \\
(0.0200)\end{array}$ & & \\
\hline BC $\times$ Low energy dependence & & & $\begin{array}{c}-0.0506^{* * *} \\
(0.0164)\end{array}$ & \\
\hline BC $\times$ High energy dependence & & & $\begin{array}{c}-0.0357^{*} \\
(0.0183)\end{array}$ & \\
\hline $\mathrm{BC} \times$ Small pollution abatement costs & & & & $\begin{array}{c}-0.0459 * \\
(0.0260)\end{array}$ \\
\hline $\mathrm{BC} \times$ High pollution abatement costs & & & & $\begin{array}{l}-0.0318 \\
(0.0258)\end{array}$ \\
\hline High institutional ownership & $\begin{array}{c}0.0070 \\
(0.0103)\end{array}$ & & & \\
\hline Large stock of green patents & & $\begin{array}{c}0.1561 * * * \\
(0.0163)\end{array}$ & & \\
\hline High energy dependence & & & $\begin{array}{l}-0.0064 \\
(0.0056)\end{array}$ & \\
\hline High pollution abatement cost & & & & $\begin{array}{r}-0.0096 \\
(0.0140)\end{array}$ \\
\hline Year fixed effects & Yes & Yes & Yes & Yes \\
\hline Firm fixed effects & Yes & Yes & Yes & Yes \\
\hline State and industry trends & Yes & Yes & Yes & Yes \\
\hline Controls & Yes & Yes & Yes & Yes \\
\hline Number of observations & 13,291 & 9,569 & 11,761 & 9,953 \\
\hline
\end{tabular}




\section{Table A1. \\ Green patents}

This table illustrates the patent utility codes (provided by the USPTO) used to classify green patents. The grouping and definition of each class follows Carrion-Flores and Innes (2010).

\begin{tabular}{ll}
\hline \hline Air pollution control & $015,044,060,110,123,422,423$ \\
Alternative energy & $049,062,204,222,228,242,248,425,428,708,976$ \\
Alternative energy sources & $062,222,425$ \\
Geothermal energy & 060,436 \\
Recycling & $060,075,099,100,106,162,164,198,201,205,210,216,229$, \\
& $264,266,422,425,431,432,460,502,523,525,536,902$ \\
Solid waste control & $034,060,065,075,099,106,118,119,122,137,162,165,203$, \\
Solid waste disposal & $205,209,210,239,241,266,405,422,423,431,435,976$ \\
Solid waste prevention & $065,119,137,165,205,210,405,435$ \\
Water pollution & $203,210,405$ \\
Wind energy & $073,104,180,242,280,340,343,374,422,440$ \\
\hline \hline
\end{tabular}




\section{Table A2. \\ List of variables}

Name

Description

Source

Innovation variables

Patent counts
Cite-weighted patent
counts
Green patent counts
Cite-weighted green
patent counts
Large (small) stock of
green patents

Count of a firm's number of patents

Count a firm's number of patents weighed by future citations received and adjusted for truncation (as described in Hall et al. 2001; Hall et al. 2005)

Count of a firm's number of green patents

NBER

Count a firm's number of green patents weighed by future citations received and adjusted for truncation (as described in Hall et al. 2001; Hall et al. 2005)

Dummy set equal to $1(0)$ if the firm has a stock of green patents above (below) the median value; the stock of green patents is computed using the cite-weighted green patent count and a perpetual inventory method while assuming a 15\% annual depreciation rate

Green patents to all patent counts

Ratio of a firm's green patent count to its total patent count (for the definition of "green" patents, see Table A1)

Energy patents to all patent counts

Ratio of a firm's energy patent count to its total patent count (for the definition of “energy" patents, see Popp and Newell 2011)

Renewable to all

Ratio of a firm's renewable energy patent count to its total patent count (for the patent counts definition of "renewable energy" patents, see Johnstone et al. 2010)

NBER
NBER
NBER
NBER
NBER
NBER
NBER

Firm characteristics

\begin{tabular}{l|l|l}
\hline $\operatorname{Ln}($ Sales $)$ & $\begin{array}{l}\text { Logarithm of a firm's sales } \\
\operatorname{Ln}(K / L)\end{array}$ & $\begin{array}{l}\text { Logarithm of the ratio of capital (property, plants, and equipment) to labor } \\
\text { (employees) } \\
\text { Ln(Age) }\end{array}$ \\
\hline
\end{tabular}

\section{Industry and state characteristics}

\begin{tabular}{l|l|l}
\hline HHI & $\begin{array}{l}\text { Herfindahl-Hirschman index, computed as the sum of squared market shares of } \\
\text { all firms (by sales) in a given 3-digit SIC industry in each year; we drop 2.5\% of } \\
\text { the observations in the right tail of the distribution in order to minimize potential } \\
\text { misclassification (cf. Giroud and Mueller 2010) }\end{array}$ & $\begin{array}{l}\text { Compustat } \\
\text { Industry trends } \\
\text { industry, where averages are computed excluding the firm in question }\end{array}$ \\
State trends & $\begin{array}{l}\text { Average of the dependent variable across all firms in the same state of location of } \\
\text { the firm, where averages are computed excluding the firm in question }\end{array}$ \\
$\begin{array}{l}\text { High (low) pollution } \\
\text { abatement costs }\end{array}$ & $\begin{array}{l}\text { Dummy set equal to 1 (0) if the firm operates in a state with pollution abatement } \\
\text { costs above (below) the median value; "pollution abatement costs" are computed }\end{array}$ & $\begin{array}{l}\text { Levinson } \\
(2001),\end{array}$
\end{tabular}


High (low) energy dependence by Levinson (2001) and Keller and Levinson (2002) using data from the Pollution Abatement Costs and Expenditures Survey taken by the US Census Bureau, and the index is computed at the state level after adjusting for industrial composition at the 2-digit SIC level (20-39)

Dummy set equal to $1(0)$ if the firm operates in an industry whose energy dependence is above (below) the median value; we use the NBER manufacturing data set to compute "energy dependence" as the ratio of energy expenses (cost of electric and fuels) to total value added

Governance characteristics

\begin{tabular}{l|l|l}
\hline $\mathrm{BC}$ & $\begin{array}{l}\text { Dummy set equal to 1 starting in the year that a business combination law was } \\
\text { passed by the state where the firm is incorporated and to 0 otherwise - that is, } \\
\text { for the years prior to BC law passage and for all years in states that never passed } \\
\text { a BC law (see Table 1 for a listing of the dates of passage) } \\
\text { Dummy set equal to 1 }(0) \text { if the firm has a fraction of equity held by institutional } \\
\text { High (low) }\end{array}$ & $\begin{array}{l}\text { Thompson } \\
\text { Financial } \\
\text { CDA/ } \\
\text { Spectrum }\end{array}$ \\
\hline \hline
\end{tabular}

